\title{
Expression of Bacteroides fragilis virulence markers in vitro
}

\author{
R. FERREIRA, M. C. F. AleXANDRE, E. N. F. ANTUneS, A. T. PINHÃO*, S. R. MORAES, M. C. S. \\ FERREIRA and R. M. C. P. DOMINGUES
}

Instituto de Microbiologia, UFRJ, Rio de Janeiro and *FIOCRUZ, Rio de Janeiro, RJ, Brazil

\begin{abstract}
Bacteroides fragilis isolates from intestinal and non-intestinal infections, normal flora and the environment were examined for properties linked with interactions among cells in vitro. Different adhesion molecules were detected in agglutination assays with human erythrocytes and tests for auto-agglutination and adherence to human colon carcinoma cells (HT29). There was no correlation between these properties, indicating that independent molecules are involved. Treatment with trypsin, heat or EDTA inhibited agglutination and adherence, suggesting that these molecules are proteins. The lack of correlation with the origin of the strains did not permit any of these activities to be recognised as virulence markers. The expression of fragilysin, a protease associated with damage to intestinal cells and bacterial translocation, was examined. Only those strains from patients with diarrhoea expressed this protease activity in assays with HT29 cells and this was confirmed by specific PCR for the bft gene. The activity of fragilysin as an enterotoxin was confirmed in the rabbit intestinal ligated loop assay. The association of this property only with strains from intestinal infections indicates that it is too early to suggest this protease as a determinant factor of $B$. fragilis invasiveness.
\end{abstract}

\section{Introduction}

Bacteroides fragilis is considered to be the most virulent species in the genus Bacteroides because of its virulence factors and its predominance among isolates from infections, despite its presence as only a small component of the normal intestinal microflora [1]. Adhesion properties, demonstrated in assays of haemagglutination and adherence to cell cultures, have been related to virulence. Surface structures such as the polysaccharide capsule [2,3], fimbriae [4], microcapsule and outer membrane non-fimbrial proteins [5] have been linked with adhesion to host cells, but without precise definition of the mechanisms. B. fragilis also produces an enterotoxin that causes diarrhoea in animals [6] and has been associated with diarrhoea in man [7]. The toxin has been purified and characterised as a zinc-metalloprotease [8], with activity against tight junction proteins, disrupting the intestinal epithelial barrier [9]. Its activity has been linked with diarrhoea and fluid loss, and also to bacterial translocation from the intestinal environment. Some authors have des-

Received 10 Nov. 1998; revised version received 25 March 1999; accepted 8 April 1999.

Corresponding author: Dr R. M. C. P. Domingues (e-mail: immmreg@microbio.ufrj.br). cribed toxin expression in strains isolated from nonintestinal infections [10]. This protease has now been named fragilysin and is encoded by the $b f t$ gene. In the present study, B. fragilis isolates from different origins were compared with clinical isolates in relation to their adhesive properties, the presence of the bft gene and fragilysin production, with the aim of detecting in vitro possible virulence markers for the species.

\section{Materials and methods}

\section{Bacterial isolates and culture conditions}

Fifty-eight isolates of $B$. fragilis from different origins were analysed. They were isolated from human nonintestinal infections (20), human intestinal microflora (14), animal intestinal microflora (5) and polluted aquatic environment (11). Four human intestinal isolates, previously defined as enterotoxigenic $(078320$ and 079298-3) and non-enterotoxigenic (283-2-1 and 077225-2) and two animal intestinal isolates (Bd1 and 865193-4), given by Dr Lyle Myers (Montana University, USA) were included. Two reference strains obtained from the American Type Culture Collection, Rockville, MD, USA (ATCC 25285 and ATCC 23745) were also studied. One Escherichia coli LT-producing strain $(40 \mathrm{~T})$, given by Dr Beatriz Guth (Escola 
Paulista de Medicina, São Paulo, Brazil) was used as positive control in rabbit intestinal ligated loop assays. Isolation and identification were performed by conventional methods, with PRAS medium [11] and the strains were stored in skim-milk $10 \%$ at $-20^{\circ} \mathrm{C}$.

\section{Haemagglutination and auto-agglutination assays}

Organisms grown in BHI-PRAS [11] for $18 \mathrm{~h}$ at $37^{\circ} \mathrm{C}$ were pelleted by centrifugation, washed and resuspended in $0.01 \mathrm{M}$ phosphate-buffered saline (PBS) $\mathrm{pH} 7.2$, to a concentration of $c .3 .0 \times 10^{10} \mathrm{cfu} / \mathrm{ml}$. Fifty $\mu \mathrm{l}$ of the bacterial suspension were serially diluted in two-fold series in a microtitration tray and $50 \mu \mathrm{l}$ of the human $\mathrm{A}^{+}$erythrocyte suspension (1\%) were added to each well, except in one, for the autoagglutination assay. The microtitration tray was shaken gently for $1 \mathrm{~min}$ at room temperature and then was read after incubation at $4^{\circ} \mathrm{C}$ for $60 \mathrm{~min}$. An extra incubation, overnight at $4^{\circ} \mathrm{C}$, was also done. Haemagglutination activity (HA) titres were expressed as the highest bacterial dilution that showed haemagglutination activity. The auto-agglutination activity (AA) was evaluated in a scale ranging from $1+$ to $4+[12]$.

\section{Haemagglutination and auto-agglutination inhibition assays}

The haemagglutination and auto-agglutination assays were done as described above, with untreated suspensions as controls and test suspension treated as follows. The bacterial suspension were heated at $100^{\circ} \mathrm{C}$ for $30 \mathrm{~min}$ and $80^{\circ} \mathrm{C}$ for $1 \mathrm{~h}$. Assays were done with the addition of $50 \mu \mathrm{l}$ of a $2.5 \mathrm{mM}$ EDTA solution, $\mathrm{pH} 7.8$, to each well. Pelleted cells were resuspended in $1 \mathrm{ml}$ of trypsin (Gibco-BRL) $2 \mathrm{mg} / \mathrm{ml}$ solution, $\mathrm{pH} \mathrm{7.8,} \mathrm{incu-}$ bated with shaking at $37^{\circ} \mathrm{C}$ for $45 \mathrm{~min}$, centrifuged and resuspended in PBS. After further centrifugation, pelleted cells were resuspended in bovine serum albumin (BSA; Sigma) $5 \mathrm{mg} / \mathrm{ml}$ in PBS.

\section{HT29 cell culture}

HT29 cells were grown in culture flasks in Dulbecco's medium with glutamine, supplemented with penicillin $100 \mathrm{IU} / \mathrm{ml}$, streptomycin $100 \mu \mathrm{g} / \mathrm{ml}$ and fetal bovine serum $10 \%$ (hereafter referred to as medium), at $37^{\circ} \mathrm{C}$ in air with $\mathrm{CO}_{2} 5 \%$. Cells were transferred to fresh medium twice a week.

\section{Adherence to HT29 cells}

Radiolabelled bacteria were prepared by growth in $5 \mathrm{ml}$ of BHI-PRAS containing $\mathrm{S}^{35}$ methionine $(100 \mu \mathrm{Ci} / \mathrm{ml})$. The cultures were incubated anaerobically for $24 \mathrm{~h}$ at $37^{\circ} \mathrm{C}$. HT29 cell-culture monolayers were prepared in Falcon multiwell trays $\left(2 \mathrm{~cm}^{2}\right.$ wells $)$. Confluent cell layers were washed twice with PBS immediately before use. Radiolabelled bacteria were washed three times with PBS and resuspended to $\mathrm{OD}_{550} 0.4$ $\left(10^{9}\right.$ bacteria $\left./ \mathrm{ml}\right)$. Bacterial suspension $(0.5 \mathrm{ml})$ was added to each of the monolayers. Trays were shaken on a plate shaker for $150 \mathrm{~min}$ at room temperature. The unbound bacteria were removed by washing the cells three times with PBS; finally, PBS $(0.5 \mathrm{ml})$ was added to each well. All cells were lysed with $1.5 \mathrm{ml}$ of sodium dodecyl sulphate (SDS) $5.5 \% \mathrm{w} / \mathrm{v}$ overnight at room temperature. The amount of radioactivity was determined by liquid scintillation counting. The radioactivity bound in the assay was compared with the total count in unwashed cells to give a percentage adherence value [3].

\section{Inhibition of adherence assays}

The reference strain ATCC 25285 was radiolabelled and treated with heat, trypsin and EDTA as described above in the haemagglutination inhibition assays. The adherence assay was done with and untreated suspension as control.

\section{Hydrophobicity level}

Organisms were grown in BHI-PRAS [11] for $18 \mathrm{~h}$ at $37^{\circ} \mathrm{C}$ and then washed three times with PBS and resuspended to $\mathrm{OD}_{660}$ 0.4. Xylene 1:2.5 (v:v) was added to the bacterial suspension, shaken in a 'vortex' mixer for $2 \mathrm{~min}$, and then kept at room temperature for $20 \mathrm{~min}$. The $\mathrm{OD}_{660}$ of the lower phase was determined. The hydrophobicity level (HL) was calculated from the formula:

$$
\mathrm{HL}=\frac{0.4-0 \mathrm{D}}{0.4} \times 100 \%[13]
$$

The isolates with percentages $>50 \%$ were considered hydrophobic.

\section{Fragilysin activity}

Organisms were grown overnight in BHI-PRAS at $37^{\circ} \mathrm{C}$. The cultures were centrifuged at $4000 \mathrm{~g}$ for $10 \mathrm{~min}$ and the supernates were frozen immediately and kept at $-20^{\circ} \mathrm{C}$ until used. HT29 cells from one flask were resuspended in $20 \mathrm{ml}$ of medium, distributed into a 96-well microtitration plate $(200 \mu \mathrm{l} /$ well $)$ and allowed to grow for 2-3 days. Before the assay the medium was removed and $180 \mu \mathrm{l}$ of fresh medium without serum were added to each well: $20 \mu \mathrm{l}$ of bacterial culture supernates were inoculated into the wells in quadruplicate. The plate was incubated at $37^{\circ} \mathrm{C}$ in air with $\mathrm{CO}_{2} 5 \%$ and then examinated after 2 and $4 \mathrm{~h}$. The culture supernates were considered to contain fragilysin if a cytopathic effect was visible [14].

\section{Enterotoxin activity in the ligated intestinal loop assay}

B. fragilis supernates from cultures in log phase $\left(\mathrm{HT}_{29}{ }^{+}\right.$and $\left.{ }^{-}\right)$were injected into loops in the proximal ileum of adult rabbits, which were then killed 
after $18 \mathrm{~h}$ and examined for the secretory response in the ligated loops. Sterile BHI and PBS were used as negative controls and the $E$. coli strain $40 \mathrm{~T}\left(\mathrm{LT}^{+}\right)$as a positive control [15].

\section{Detection of fragilysin gene (bft)}

Pure genomic DNA from all strains tested was obtained by a standard miniprep procedure [16]. The concentration of DNA in the samples was determined by spectrophotometry with the GenQuant apparatus (Pharmacia). PCR was used to obtain the DNA fragment of the $b f t$ gene, with the specific primers: 5'-TGTGGAATCACATCGTGCATCA-3' $3^{\prime}$ and 5'-AGTTCGCCGCATCCTGCATCTG-3' (Gibco-BRL). PCR was performed with Taq polymerase $1.25 \mathrm{U}$ (Gibco-BRL) in $50 \mu \mathrm{l}$ containing chromosomal DNA $(50 \mathrm{ng})$, primers $(80 \mathrm{pmol})$, deoxynucleoside triphosphates $(200 \mu \mathrm{M})$ and $1.5 \mathrm{mM} \mathrm{MgCl}_{2}$. The amplification cycle was denaturation at $94^{\circ} \mathrm{C}$ for $1 \mathrm{~min}$, annealing at $66^{\circ} \mathrm{C}$ for $2 \mathrm{~min}$ and extension at $72^{\circ} \mathrm{C}$ for $5 \mathrm{~min}$ [17]. The amplified product was analysed by agarose gel electrophoresis.

\section{Results}

Different adhesion patterns were detected in the haemagglutination and auto-agglutination assays with the 58 isolates (Tables 1 and 2): $\mathrm{HA}^{+} \mathrm{AA}^{-}$strains (18 isolates), $\mathrm{HA}^{+} \mathrm{AA}^{+}$strains (13), $\mathrm{HA}^{-} \mathrm{AA}^{+}$strains (1) and $\mathrm{HA}^{-} \mathrm{AA}^{-}$strains (26). However, when BSA was used in the inhibition tests, these patterns were altered, as in many cases the inhibition of AA determined the loss of HA (strains 1103-4 and 1118-1 in Table 1 and strains 0783220 and $\mathrm{Bdl}$ in Table 2). Based on these results the groups were re-arranged: $\mathrm{HA}^{+} \mathrm{AA}^{-}$strains
(18), $\mathrm{HA}^{+} \mathrm{AA}^{+}$strains (9), $\mathrm{HA}^{-} \mathrm{AA}^{+}$strains (1) and $\mathrm{HA}^{-} \mathrm{AA}^{-}$strains (30). Treatment with trypsin, heat and EDTA inhibited HA and AA of all strains. In the assays for determination of surface hydrophobicity, 15 of 22 isolates from non-intestinal infections were defined as hydrophobic and seven as hydrophilic (Table 1). In the group of 36 isolates from intestinal infections, intestinal microflora and from polluted aquatic environment 22 isolates were defined as hydrophobic and 14 as hydrophilic (Table 2).

When a selected group of nine isolates from different sources, without AA and with different HA titres, was assayed with HT29 cells, the percentage of adherence ranged from $7.7 \%$ to $30 \%$ (Table 3 ). The number of adhering bacteria/cell was calculated for each isolate and isolates with $<150$ bacteria/cell were considered poorly adherent (0), moderately adherent isolates (3) had 150-300 bacteria/cell and highly adherent strains (6) had $>300$ bacteria/cell.

Treatment with trypsin, heat and EDTA inhibited the cell adhesion capacity of strain ATCC 25285.

In all 58 isolates analysed, it was possible to verify that only two isolates originating from diarrhoea samples (strains 078320 and 079298-3) were able to express fragilysin in assays with HT29 cells, causing rounded cells after incubation for $2-4 \mathrm{~h}$. The other isolates analysed originated from non-intestinal infections, human intestinal microflora, animal intestinal microflora, polluted aquatic environment, animal intestinal infections and also human intestinal infections (strains 283-2-1 and 077225-2) did not show cytotoxicity to HT29 cells. The supernates of strains 078320 and 079298-3 were serially diluted in Dulbecco's medium

Table 1. Determination of haemagglutination (HA), auto-agglutination (AA) and surface hydrophobicity ( $\mathrm{SH})$ in $B$. fragilis isolates from non-intestinal infections

\begin{tabular}{|c|c|c|c|c|c|c|}
\hline Source & Isolate no. & HA titre & HA BSA & AA & AA BSA & $\mathrm{SH}$ \\
\hline \multirow[t]{2}{*}{ ATCC reference } & 25285 & 0 & NT & 0 & NT & + \\
\hline & 23745 & 4 & 4 & 0 & 0 & + \\
\hline \multirow[t]{3}{*}{ Chronic otitis media } & $036 \mathrm{M}$ & 0 & NT & 0 & NT & + \\
\hline & $016 \mathrm{M}$ & 2 & 2 & $1+$ & $1+$ & + \\
\hline & $023 \mathrm{~A}$ & 4 & 4 & 0 & 0 & - \\
\hline \multirow[t]{5}{*}{ Intra-abdominal infections } & $1058-1$ & 0 & NT & 0 & NT & - \\
\hline & $1031,1304-3 a$ & 2 & 2 & 0 & 0 & - \\
\hline & $1304-2$ & 8 & 8 & 0 & 0 & + \\
\hline & $1103-4$ & 2 & 0 & $4+$ & 0 & + \\
\hline & $1048-\mathrm{a}$ & 8 & 8 & $3+$ & $3+$ & + \\
\hline \multirow[t]{3}{*}{ Bacteraemia } & 1081 & 2 & 2 & 0 & 0 & + \\
\hline & 1032 & 2 & 2 & 0 & 0 & - \\
\hline & 1241 & 8 & 8 & $3+$ & $3+$ & + \\
\hline \multirow[t]{4}{*}{ Skin and soft tissue infections } & 1097 & 0 & NT & 0 & NT & + \\
\hline & $1108-3 b$ & 0 & NT & 0 & NT & - \\
\hline & $\mathrm{MCl}$ & 2 & 2 & 0 & 0 & - \\
\hline & 1118-1 & 64 & 0 & $4+$ & 0 & + \\
\hline \multirow[t]{3}{*}{ Miscellaneous } & MC2, 1292 & 0 & NT & 0 & NT & + \\
\hline & 1034 & 2 & NT & 0 & NT & + \\
\hline & $1270-3 \mathrm{al}$ & 8 & 8 & $3+$ & $3+$ & + \\
\hline
\end{tabular}

HA titre, highest bacterial dilution that showed agglutination of human erythrocytes $\mathrm{A}+$; HA BSA, haemagglutination titre in the presence of BSA $5 \mathrm{mg} / \mathrm{ml}$, AA, bacterial suspension only, evaluated on a scale from $1+$ to $4+$; AA BSA, auto-agglutination evaluated with BSA $5 \mathrm{mg} / \mathrm{ml}$; $\mathrm{SH}$, phase partition in xylene, $>50 \%$ hydrophobic $(+),<50 \%$ hydrophilic $(-)$; NT, not tested. 
Table 2. Determination of haemagglutination (HA), auto-agglutination (AA) and surface hydrophobicity (SH) in $B$. fragilis isolates from human intestinal infections, animal intestinal infections, human intestinal microflora, animal intestinal microflora and polluted aquatic environment

\begin{tabular}{|c|c|c|c|c|c|c|}
\hline Source & Isolate no. & HA titre ${ }^{l}$ & HA BSA & $\mathrm{AA}$ & AA BSA & $\mathrm{SH}$ \\
\hline \multirow[t]{8}{*}{ Human intestinal microflora } & 108311, Re51, & 0 & NT & 0 & NT & + \\
\hline & $\mathrm{F} 4, \mathrm{~F} 26-6$ & 0 & NT & 0 & NT & + \\
\hline & FF 15, F22, FN17-80 & 0 & NT & 0 & NT & - \\
\hline & $\mathrm{F} 1, \mathrm{FF} 10$ & 2 & 2 & 0 & 0 & + \\
\hline & FF 14, F43-6 & 2 & 2 & 0 & 0 & + \\
\hline & F21 & 4 & 4 & 0 & 0 & + \\
\hline & $\operatorname{Re} 32$ & 4 & 4 & $3+$ & $3+$ & + \\
\hline & 118310 & 2 & 2 & 0 & 0 & - \\
\hline \multirow[t]{3}{*}{ Animal intestinal microflora } & $\mathrm{Cl02b}$ & 0 & NT & 0 & NT & + \\
\hline & $\mathrm{P} 1, \mathrm{P} 2, \mathrm{P} 3$ & 0 & NT & 0 & NT & - \\
\hline & $\mathrm{C} 102 \mathrm{a}$ & 4 & 4 & 0 & 0 & - \\
\hline \multirow[t]{3}{*}{ Human intestinal infection } & 078320 & 2 & 0 & $1+$ & 0 & - \\
\hline & $079298-3,077225-2$ & 0 & NT & 0 & NT & + \\
\hline & $283-2-1$ & 0 & NT & 0 & NT & - \\
\hline \multirow[t]{2}{*}{ Animal intestinal infection } & $\mathrm{Bd} 1$ & 2 & 0 & $4+$ & 0 & - \\
\hline & $865193-4$ & 16 & 16 & $4+$ & $4+$ & - \\
\hline \multirow[t]{9}{*}{ Polluted aquatic environment } & AA 10 & 2 & 2 & 0 & 0 & - \\
\hline & AA41-1 & 2 & 2 & $1+$ & $1+$ & - \\
\hline & AA41-4 & 0 & 0 & $1+$ & 0 & + \\
\hline & AA1, AA41-3, & 0 & NT & 0 & NT & + \\
\hline & AA41-4, AA42-1 & 0 & NT & 0 & NT & + \\
\hline & AA42-2 & 0 & NT & 0 & NT & + \\
\hline & $\mathrm{AA} 3$ & 8 & 8 & 0 & 0 & + \\
\hline & $\mathrm{AAa}$ & 8 & 8 & $3+$ & $3+$ & + \\
\hline & AA7 & 16 & 16 & $4+$ & $4+$ & + \\
\hline
\end{tabular}

See footnote to Table 1 .

Table 3. Determination of adherence to HT29 cells by B. fragilis isolates from non-intestinal infections, human intestinal infections, human intestinal microflora and polluted aquatic environment, with and without HA

\begin{tabular}{|c|c|c|c|c|c|}
\hline Source & Isolate nos. & HA titre & $\mathrm{SH}$ & Adherence $(\%)^{*}$ & $\begin{array}{c}\text { Number of } \\
\text { bacteria/cell }\end{array}$ \\
\hline \multirow[t]{3}{*}{ Extraintestinal infections } & $25285^{\ddagger}$ & 0 & 55 & 21.9 & 548 \\
\hline & $023 \mathrm{~A}^{\S}$ & 4 & 45 & 15.5 & 388 \\
\hline & $1304-2^{\|}$ & 8 & 70 & 15.6 & 390 \\
\hline \multirow[t]{3}{*}{ Human intestinal infections } & $0772252^{\circ}$ & 0 & 55 & 14.2 & 355 \\
\hline & $079298-3^{* *}$ & 0 & 55 & 10.6 & 265 \\
\hline & $078320^{* *}$ & 2 & 45 & 7.8 & 195 \\
\hline Human intestinal microfiora & FF15 & 0 & 50 & 20.3 & 508 \\
\hline \multirow[t]{2}{*}{ Polluted aquatic environment } & AA1 & 0 & 50 & 30.0 & 750 \\
\hline & AA3 & 8 & 50 & 11.0 & 275 \\
\hline
\end{tabular}

$\mathrm{HA}, \mathrm{SH}$, see footnote to Table 1 .

* percentage adherence, difference between total radioactivity in the inoculum added and radioactivity bound in the assay.

number of bacteria/cell, calculated from estimated number of cells/well $\left(2 \times 10^{5}\right.$ in $\left.2 \mathrm{~cm}^{2}\right)$ and the bacterial inoculum $\left(1 \times 10^{8}\right)$, related to the percentage adherence.

${ }^{\ddagger}$ ATCC reference strain.

${ }^{\S}$ From chronic otitis media.

"From intra-abdominal infection.

Non-enterotoxigenic strain

** Enterotoxigenic strains.

without fetal serum, and the cytotoxic titres were 8 and 128, respectively (Table 4 ).

The enterotoxic activity of fragilysin was also confirmed in the rabbit intestinal ligated loop assay when the supernates of the cytotoxic strains were assayed.

The presence of the fragilysin gene was confirmed by PCR with specific primers for the bft gene; all 58 strains were assayed and 900-bp bands in agarose gel electrophoresis were found only in the cytotoxic strains 078320 and 079298-3 (Fig. 1).

\section{Discussion}

In this study, the HA technique was used to characterise the adherence properties of isolates, considered to represent the factor that may contribute to the prevalence of $B$. fragilis in infections. The capacity for HA and AA have been associated with more virulent strains [12]. These mechanisms have not yet been explained in molecular terms, although a proteic nature for the molecules involved has been suggested [18]. A direct relationship between the surface hydrophobicity and both approximation and interaction 
Table 4. Determination of cytotoxic activity for HT29 cells and detection of $b f t$ gene by PCR

\begin{tabular}{lcc}
\hline Isolate no. & $\begin{array}{c}\text { Cytotoxic titre } \\
\text { (HT29) }\end{array}$ & bft gene (PCR) ${ }^{*}$ \\
\hline $25285,23745^{\dagger}$ & 0 & - \\
$078320^{\ddagger}$ & 8 & + \\
$079298-3^{+}$ & 128 & + \\
$283-2-1^{\ddagger}$ & 0 & - \\
$077225-2^{\star}$ & 0 & - \\
Other isolates & 0 & - \\
\hline
\end{tabular}

* PCR product with specific primers.

${ }^{\dagger}$ ATCC reference strains.

${ }^{\ddagger}$ Strains given by Dr Lyle Myers, Montana University, EUA, from human intestinal infection, as positive $(078320,079298-3)$ and negative (283-2-1, 077225-2) controls of enterotoxin production in lamb ligated intestinal loop assay. All other 52 isolates were tested by both assays and did not have either cytotoxic activity or bft gene presence.

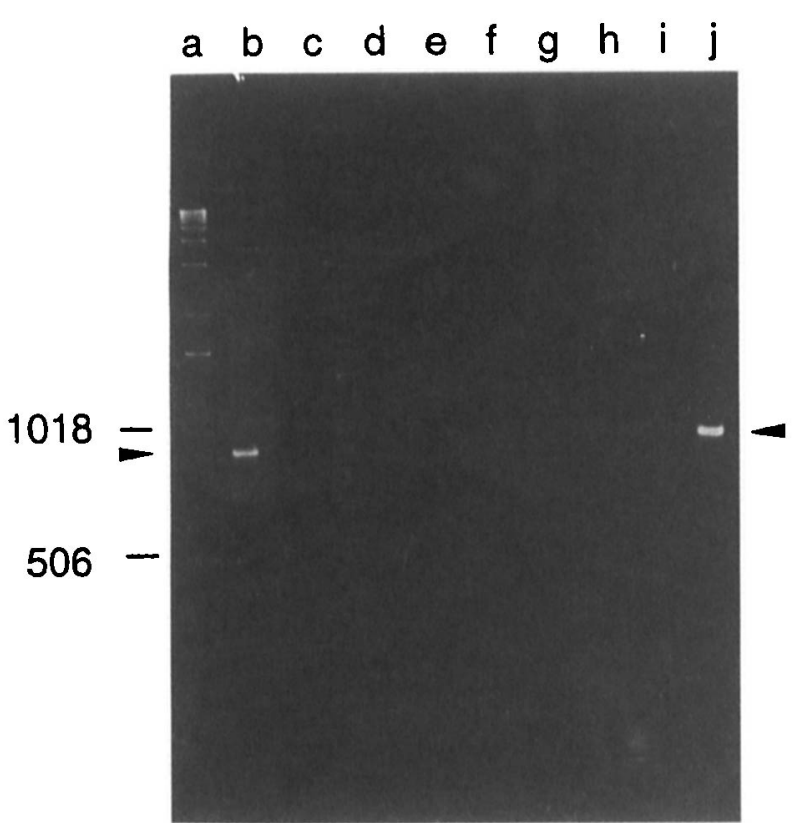

Fig. 1. Detection of $b f t$ gene by PCR analysis and agarose $(1.0 \%)$ gel electrophoresis. Bands of $c .900 \mathrm{bp}$ were detected only in the two isolates from diarrhoeic sources (arrow). Line a, mol.wt standard (Gibco, $1 \mathrm{~kb}$ ); b, DNA amplified from strain 079298-3; c, 283-2-1; d, 0772252-5; e, ATCC 25285; f, ATCC 23745; g, AA1; h, $\mathrm{Bdl} ; \mathbf{i}, \mathrm{FF} 15 ; \mathbf{j}, 078320$.

between bacteria and other surfaces has been proposed [19]. In the present study, HA was totally inhibited by physicochemical treatments, suggesting that the haemagglutinins present have a proteic nature and an activity dependent on metallic ions. Bovine serum albumin was capable of inhibiting $\mathrm{AA}$ and $\mathrm{HA}$ in the isolates studied; however, hydrophobicity and the origins of isolates do not seem to be related to AA and HA.

Adherence by $B$. fragilis has also been analysed in other cell culture systems. Oyston and Handley [3] verified lower levels of adhesion of buccal epithelial cells than to intestinal epithelial HT29 cells. In testing the adherence of $B$. fragilis to HT29 cells, it was verified that isolates with higher titres of HA were less adherent to the cells, which could suggest the existence of different molecules responsible for the two features. Thus, HA determination was not satisfactory as a selection criterion for isolates adherent to intestinal epithelial cells (HT29). Treatment with heat, trypsin and EDTA produced significant reduction in the adhesion of isolates to HT2 9 cells, suggesting a proteic nature for both molecules involved. The surface hydrophobicity levels did not correspond with the adherence properties demonstrated, suggesting selectivity in the adhesion. There was no correlation between adherence properties and the sources of isolates; consequently, it was not possible to propose them as virulence markers.

Only two $B$. fragilis isolates from intestinal infections expressed fragilysin, and there was complete correlation between phenotypic (HT29) and genotypic (PCR) methods of detection. The PCR assay proved to be a good methodological choice for fragilysin detection, due to its speed and ease of reading. The evaluation of enterotoxin activity by rabbit ligated intestinal loop assay was successful; however, some authors do not recommend this experimental animal model, because it is less sensitive than the lamb ligated intestinal loop [20].

The fragilysin molecule was characterised as a zincmetalloprotease [8] that induces alterations in the intestinal epithelial cells, mainly in the tight junction proteins with disruption of the epithelial barrier [21]. The histological responses suggest a role for fragilysin as a factor that could act in the initial stages of nonintestinal infectious processes caused by $B$. fragilis. Kato et al. [10] proposed that enterotoxigenic $B$. fragilis (ETBF) was preferentially associated with bacteraemia. It has also been shown that the presence of the toxin increased the internalisation of enteric bacteria, such as Salmonella typhimurium and E. coli by HT29 cells [22], leading to the belief that fragilysin may contribute to the disruption of the barrier against non-intestinal infections. In the present study, the isolates from invasive infections did not produce fragilysin, as would be expected. There was a correlation between isolates from intestinal infections and the presence of fragilysin. Mundy and Sears [23] also found a small number of ETBF in non-intestinal infections. Thus, it seems too early to suggest this protease as a determinant factor of $B$. fragilis invasiveness, and more studies are needed.

This work was supported by grants from the following Institutions: CNPq, FUJB, FINEP-BID, CEPG, PRONEX and FAPERJ.

\section{References}

1. Finegold SM, Baron EJ, Wexler HM, Tester HJR. A clinical guide to anaerobic infections. Belmont, Star Publishing. 1992. 
2. Pruzzo C, Guzmán CA, Danielli B. Incidence of hemagglutination activity among pathogenic and non-pathogenic Bacteroides fragilis strains and role of capsule and pili in $\mathrm{HA}$ and adherence. FEMS Microbiol Lett 1989; 50: 113-118.

3. Oyston PCF, Handley PS. Surface components of Bacteroides fragilis involved in adhesion and haemagglutination. $J$ Med Microbiol 1991; 34: 51-55.

4. Pruzzo C, Danielli B, Riechetti M. Piliated Bacteroides fragilis strains adhere to epithelial cells and are more sensitive to phagocytosis by human neutrophils than nonpiliated strains. Infect Immun 1984; 43: 189-194.

5. Patrick S, Coffey A, Emmerson AM, Larkin MJ. The relationship between cell surface structure expression and hemagglutination in Bacteroides fragilis. FEMS Microbiol Lett 1988; 50: 67-71.

6. Myers LL, Firehammer BD, Shoop DS, Border MM. Bacteroides fragilis: a possible cause of acute diarrheal disease in newborn lambs. Infect Immun 1984; 44: 241-244.

7. Myers LL, Shoop DS, Stackhouse LL et al. Isolation of enterotoxigenic Bacteroides fragilis from humans with diarrhea. J Clin Microbiol 1987; 25: 2330-2333.

8. Moncrief JS, Obiso R, Barroso LA et al. The enterotoxin of Bacteroides fragilis is a metalloprotease. Infect Immun 1995; 63: $175-181$.

9. Koshy SS, Montrose MH, Sears CL. Human intestinal epithelial cells swell and demonstrate actin rearrangement in response to the metalloprotease toxin of Bacteroides fragilis. Infect Immun 1996; 64: 5022-5028.

10. Kato $\mathrm{N}$, Kato $\mathrm{H}$, Watanabe $\mathrm{K}$, Ueno $\mathrm{K}$. Association of enterotoxigenic Bacteroides fragilis with bacteremia. Clin Infect Dis 1996; 23 Suppl 1: S83-S86.

11. Summanen P, Baron EJ, Citron DM, Strong CA, Wexler HM, Finegold SM. Wadsworth anaerobic bacteriology manual, 5th edn. Belmont, CA, Star Publishing. 1993.

12. Domingues RMCP, Cavalcanti SMB, Fonseca MEF, Ferreira MCS. Haemagglutination activity of Bacteroides fragilis as a virulence marker. Rev Microbiol 1991; 22: 277-281.

13. Rosenberg M, Gutnick D, Rosenberg E. Adherence of bacteria to hydrocarbon: a simple method for measuring cell-surface hydrophobicity. FEMS Microbiol Lett 1980; 9: 29-33.

14. Pantosti A, Cerquetti M, Colangeli R, D'Ambrosio F. Detection of intestinal and extra-intestinal strains of enterotoxigenic Bacteroides fragilis by the HT-29 citotoxic assay. J Med Microbiol 1994; 41: 191-196.

15. Myers LL, Shoop DS. Association of enterotoxigenic Bacteroides fragilis with diarrheal disease in young pigs. $\mathrm{Am} \mathrm{J} \mathrm{Vet}$ Res 1987; 48: 774-775.

16. Wilson K. Preparation of genomic DNA from bacteria. In: Ausubel FM, Brent R, Kingston RE et al. (eds) Current protocols in molecular biology, 2nd edn. New York, John Wiley. 1992: 2.4.1-1.4.2.

17. Franco AA, Mundy LM, Trucksis M, Wu S, Kaper JB, Sears CL. Cloning and characterization of the Bacteroides fragilis metalloprotease toxin gene. Infect Immun 1997; 65: $1007-1013$.

18. Blake $M$, Rotstein OD, Llano $M$, Girotti MJ, Reid G. Agreggation by fragilis and non-fragilis Bacteroides strains in vitro. J Med Microbiol 1989; 28: 9-14.

19. Lachica RN. Significance of hydrophobicity in adhesiveness of pathogenic Gram negative bacteria. In: Doyle RJ, Rosemberg $M$ (eds) Microbial cell surface hydrophobicity. Washington, DC, American Society for Microbiology. 1990: 297-313.

20. Sears CL, Myers LL, Lazenby A, Van Tassell RL. Enterotoxigenic Bacteroides fragilis. Clin Infect Dis 1995: 20 Suppl 2: S142-S148.

21. Obiso RJ, Azghani AO, Wilkins TD. The Bacteroides fragilis toxin fragilysin disrupts the paracellular barrier of epithelial cells. Infect Immun 1997; 65: 1431-1439.

22. Wells CL, Van de Westerlo EMA, Jechorek RP, Feltis BA, Wilkins TD, Erlandsen SL. Bacteroides fragilis enterotoxin modulates epithelial permeability and bacterial internalization by HT29 enterocytes. Gastroenterology 1996; 110: 1429-1437.

23. Mundy LM, Sears CL. Detection of toxin production by Bacteroides fragilis: assay development and screening of extraintestinal clinical isolates. Clin Infect Dis 1996; 23 269-276. 